\title{
Prevalence of antibodies to herpes simplex virus types 1 and 2 in pregnant women, and estimated rates of infection
}

\author{
A E ADES, ${ }^{1} \mathrm{C} \mathrm{S}$ PECKHAM, ${ }^{1}$ G E DALE, ${ }^{2} \mathrm{~J} \mathrm{M} \mathrm{BEST}^{2}{ }^{2}$ AND S JEANSSON ${ }^{3}$ \\ From ${ }^{1}$ the Department of Paediatric Epidemiology, Institute of Child Health, 30 Guilford Street, London WC1; \\ ${ }^{2}$ the Department of Virology, United Medical and Dental Schools of Guy's and St Thomas' Hospitals, St Thomas' \\ Campus, London SE1; and ${ }^{3}$ the Department of Virology, Institute of Medical Microbiology, University of \\ Goteborg, Guldhedsgaten 10B, Goteborg, Sweden.
}

\begin{abstract}
There has been a recent increase in notifications of genital herpes but it is not known whether this has been reflected in the pregnant population. We have therefore carried out a study to determine the prevalence of herpes simplex antibodies in pregnant women and to estimate the incidence of primary infection. Sera were collected from 3533 women at antenatal clinics and tested for total antibodies to herpes simples virus (HSV), and if positive, for specific antibodies to HSV-2. Estimates of HSV-1 seroprevalence were derived from the HSV-2 seronegative population. HSV-1 seroprevalence was nearly $100 \%$ in black women born in Africa or the Caribbean and $60-80 \%$ in white, Asian and UK born black women. It was lower in women in non-manual employment. HSV-2 seroprevalence was related to age, rising from 0 at age 16 to $40 \%$ at age 35 in black women, and to about $10 \%$ in Asian and white women. The estimated incidence of primary HSV-2 infection during pregnancy, per 1000 pregnancies, was about 2.4 in Asian women, 5 in white women, and 20 in black women. Estimates of the incidence of neonatal infection were derived from these figures and compared to the nationally reported rates.
\end{abstract}

Maternal genital herpes infection at the time of delivery may result in infection of the newborn infant during passage through the infected birth canal, or by ascending infection after rupture of the membranes. Neonatal herpes is a serious condition with about $60 \%$ mortality. ${ }^{1-3}$ Mortality is reduced by antiviral chemotherapy, ${ }^{1}$ though many surviving infants have severe neurological and/or ocular sequelae.

The incidence of neonatal herpes varies in different populations. A rate of 13 per 100000 was reported in a largely black population in the United States. ${ }^{4}$ In England, Scotland and Northern Ireland 136 cases of neonatal infection were notified in 1976-85 through the Public Health Laboratory Service (PHLS) (Communicable Disease Surveillance Centre, unpublished). This amounts to about 14 cases per year, a rate of about 2-3 per 100000 births. In an active monthly reporting scheme, ${ }^{5}$ paediatricians in the United Kingdom have reported eight confirmed cases over 13 months during 1986/7 (British Paediatric Surveillance Unit, unpublished). However, less severe and subclinical infection may go unreported, so that these figures are likely to underestimate the true incidence.

An increase in notifications of genital herpes has been reported in clinics for sexually transmitted diseases over recent years ${ }^{67}$ but it is not known whether this increase has been reflected in the pregnant population. Current information about the prevalence, incidence and transmission of HSV infections derives from serological surveys and cytological and virus isolation studies, conducted mostly on North American populations. Widely different seroprevalences are reported in these studies, but interpretation is hampered by the variety of laboratory techniques used and the substantial cross reactivity between $\mathrm{HSV}-1$ and $\mathrm{HSV}-2$ antibodies. $^{1}$ 
Previously attempts have been made to remove antibodies to type-common antigens by prior absorption of serum with HSV-1, leaving only HSV-2 antibodies. ${ }^{8}$ This is not practical for large numbers of sera. However, it has recently become possible to produce the HSV-2 type specific antigen $\mathrm{gG}_{2}{ }^{9}$ and this has enabled us to measure the prevalence of HSV-2 specific antibodies reliably, using a sensitive enzyme linked immunosorbent assay (ELISA).

We describe here a sero-epidemiological study to determine the prevalence of $\mathrm{HSV}-1$ and HSV-2 antibodies in a population of pregnant women and to estimate the incidence of primary infection from age specific prevalence rates. The results are discussed in the light of the incidence of neonatal herpes, groups at risk and mechanisms of transmission.

\section{Methods}

\section{STUDY POPULATION}

Sera from 3533 women collected at the first antenatal clinic attendance in a West London Hospital in 1980 and 1981 were examined for HSV antibodies. These women had formed the basis for a prospective study of cytomegalovirus infection in pregnancy, ${ }^{10}$ and information on their age, parity, marital status, occupation, ethnic group and country of origin was available from questionnaires administered by nurses at the antenatal clinic. Sera collected from women attending for a subsequent pregnancy during this period were excluded.

\section{LABORATORY METHODS}

Sera were first screened for HSV antibodies by ELISA using combined HSV-1 and HSV-2 membrane antigens and an uninfected cell control antigen. ${ }^{11}$ Sera were tested at 1:200 dilution on antigen coated plates. Bound IgG antibodies were detected with horseradish peroxidase conjugated rabbit antihuman IgG (Dako Ltd, High Wycombe). HSV seropositive specimens were then tested by a similar ELISA for antibodies to HSV-2 type specific antigen $\mathbf{g G}_{2}$, prepared by Helix pomatia lectin affinity chromatography. ${ }^{9}$

Sera were considered positive if the specific absorbance, the difference between absorbances on HSV and control antigens, was greater than the mean specific absorbance +3 SD of three control sera. Seronegative sera were used as controls in the HSV assay, and HSV antibody positive sera from children with HSV-1 infection in the HSV-2 assay.

\section{STATISTICAL METHODS}

The initial serological test identified total HSV antibodies. As no HSV-1 specific antigen was available, the analysis of $\mathrm{HSV}-1$ seroprevalence is based only on women who were HSV-2 negative. This was regarded as an adequate measure of overall HSV-1 seroprevalence because there is no a priori reason to believe that $\mathrm{HSV}-1$ and $\mathrm{HSV}-2$ are necessarily acquired by the same people. Also, HSV-1 seropositivity is common in adults $(70-100 \%)$ and HSV -2 seropositivity sufficiently uncommon that any differences in HSV-1 seroprevalence between HSV-2 seropositive and seronegative individuals would have to be extreme to influence the results adversely.

Separate analyses were performed to describe overall seroprevalence of $\mathrm{HSV}-1$ and HSV-2 antibodies and to examine potential risk factors for which information was available, which were race, age, marital status and social class. The woman's own occupation was used to define social class, in view of the large number of single women in the sample; non-manual, manual and "other" groups were distinguished. The latter group included unemployed women and those not seeking employment. Data were available for race (Asian, white, black and other) and for country of birth, and this was used to define "ethnic groups" (Asian/Indian Subcontinent, Asian/ Africa, White/British Isles, Black/British Isles, Black/ Africa, Black/Caribbean). As the risk factors were highly correlated, a grouped logistic regression using the GLIM package ${ }^{12}$ was performed to examine which factors were related to serostatus when others were controlled for. Seropositivity rates are presented for the most important risk factors, indirectly standardised for the other factors. The indirectly age standardised seroprevalence of a subgroup is the seroprevalence of the standard population multiplied by a standardising ratio, namely the number of observed seropositives in the subgroup divided by the rumber that would be expected if the standard age specific rates were applied. The study populations themselves were used to define the standard rates, and the standardisation was performed separately within each ethnic group.

The incidence of HSV-2 infection was estimated from age stratified seroprevalence data. ${ }^{13-15}$ Using standard survival time theory, ${ }^{16}$ the proportion seronegative at exact age $a, \mathrm{~S}(\mathrm{a})$, was defined in terms of the force of infection $\lambda(a)$ :

$$
S(a)=\exp \left[-A_{0}^{a} \lambda(x) d x\right]
$$

Where $A_{o}$ is the age at which infection is first possible.

Following Grenfell and Anderson ${ }^{15}$ and earlier "catalytic" models ${ }^{17}$ we assume that $a$ may depend on age and express it as a polynominal of degree $k$ :

$$
\lambda(a)=\sum_{j=0}^{k} b_{j} a^{j}
$$


Combining equations (1) and (2) we get

$$
\ln S(a)=\sum_{j=0}^{k} \frac{b_{j}\left(A_{o}^{j+1}-a^{j+1}\right)}{j+1}
$$

For each ethnic group discrete time versions of such models were estimated using the GLIM package, ${ }^{12}$ with data grouped into 1 year strata. The number seronegative in each age group $S_{a}$ was modelled with a logarithmic link function and binomial error with denominator $\mathbf{N}_{\mathrm{a}}$, the total number of women at age a. ${ }^{18}$

Models were fitted with various values of $A_{o}$ and the value giving the best fit selected. $A_{o}$ is the earliest age at which individuals are at risk of acquiring infection: as HSV-2 is sexually transmitted, this age cannot logically postdate the age at antenatal clinic attendance, so the age of the youngest group was taken as a maximum for $\mathbf{A}_{\mathrm{o}}$.

Given a fitted incidence $\hat{\lambda}_{\mathrm{a}}$ and proportion seronegative $\hat{S}_{a}$ at each age $a$, and assuming a 9 month gestation period, the proportion of pregnancies in which HSV-2 seroconversion occurs can be estimated by summing over age strata as follows:

$$
0.75 \frac{\Sigma_{\mathrm{a}} \hat{\lambda}_{\mathrm{a}} \hat{\mathrm{S}}_{\mathrm{a}} \mathrm{N}_{\mathrm{a}}}{\Sigma_{\mathrm{a}} \mathrm{N}_{\mathrm{a}}}
$$

The proportion of pregnancies in which HSV-2 seroconversion occurs in an $\mathrm{HSV}-1$ negative individual was also estimated. Where $H_{a}$ is the proportion HSV-1 negative at age $a$, this is:

$$
0.75 \frac{\Sigma_{\mathrm{a}} \hat{\lambda}_{\mathrm{a}} \hat{\mathrm{S}}_{\mathrm{a}} \mathrm{H}_{\mathrm{a}} \mathrm{N}_{\mathrm{a}}}{\Sigma_{\mathrm{a}} \mathrm{N}_{\mathrm{a}}}
$$

The standard error of expression (4) was estimated by simulation. One hundred sets of age specific seronegative rates $S_{a}^{\prime}$ were generated by adding a random quantity, $r_{a}$, at each age to the fitted $\hat{S}_{a}$. It was assumed that $r_{a}$ was normally distributed with mean zero and a variance determined by the fitted seroprevalence rate, according to the normal approximation to the binomial:

$$
\mathrm{S}_{\mathrm{a}}^{\prime}=\hat{\mathrm{S}}_{\mathrm{a}}+\mathrm{r}_{\mathrm{a}}, \quad \mathrm{r} \sim \mathrm{N}\left(\mathrm{O},\left[\hat{\mathrm{S}}_{\mathrm{a}}\left(1-\hat{\mathrm{S}}_{\mathrm{a}}\right) / \mathrm{N}_{\mathrm{a}}\right]\right)
$$

A constant incidence $(k=0)$ version of equation (3) was fitted to each set of $S_{a}$ and the annual rate of pregnancies with an HSV-2 seroconversion was estimated from expression (4).
Results

HSV-1 AND HSV-2 SEROPREVALENCE

Table 1 gives the percent seroprevalence for $\mathrm{HSV}-1$ and HSV-2 for ethnic group, age, parity, social class, and marital status. Broad differences are evident in HSV-2 seroprevalence with single women more likely to be seropositive than those married or cohabiting, and black women more likely to be seropositive than Asian or white. The consistent increase in seroprevalence with age is illustrated in the figure. In the white and Asian groups there is an increase from zero at 16 years to $10 \%$ or less in the early 30 s. By contrast all three black groups show a much higher seroprevalence, over $30 \%$ becoming seropositive by age 25 . At each age the three groups of black women

\begin{tabular}{|c|c|c|c|c|}
\hline & \multicolumn{2}{|c|}{$H S V-I$} & \multicolumn{2}{|c|}{$H S V-2$} \\
\hline & $n$ & $\%$ positive & $n$ & $\%$ positive \\
\hline \multicolumn{5}{|l|}{ Ethnic group } \\
\hline Asian, Indian subcontinent & 717 & $72 \cdot 5$ & 742 & $3 \cdot 4$ \\
\hline Asian, Africa & 460 & $68 \cdot 5$ & 476 & 3.4 \\
\hline White, British Isles & 1138 & $80 \cdot 1$ & 1226 & $7 \cdot 2$ \\
\hline Black, British Isles & 215 & $75 \cdot 3$ & 252 & $14 \cdot 7$ \\
\hline Black, Africa & 106 & $96 \cdot 2$ & 169 & $36 \cdot 5$ \\
\hline Black, Caribbean & 220 & $92 \cdot 3$ & 328 & 32.9 \\
\hline Others & 301 & $81 \cdot 4$ & 332 & $9 \cdot 3$ \\
\hline \multicolumn{5}{|l|}{ Age } \\
\hline$<20$ & 521 & $74 \cdot 9$ & 545 & $4 \cdot 4$ \\
\hline $20-24$ & 1122 & $77 \cdot 3$ & 1240 & $9 \cdot 5$ \\
\hline $25-29$ & 911 & 76.6 & 1027 & $11 \cdot 3$ \\
\hline $30-34$ & 444 & 80.9 & 515 & $13 \cdot 8$ \\
\hline$\geqslant 35$ & 164 & 90.9 & 202 & $18 \cdot 8$ \\
\hline \multicolumn{5}{|l|}{ Marital status } \\
\hline Single & 686 & $82 \cdot 1$ & 821 & $16 \cdot 4$ \\
\hline Married and/or cohabiting & 2475 & 76.7 & 2707 & $8 \cdot 6$ \\
\hline \multicolumn{5}{|l|}{ Woman's social class } \\
\hline Non-manual & 1042 & $72 \cdot 2$ & 1171 & 11.0 \\
\hline Manual & 653 & $81 \cdot 6$ & 732 & $10 \cdot 8$ \\
\hline Other & 1471 & $79 \cdot 6$ & 1630 & 9.8 \\
\hline Overall rate & 3166 & $77 \cdot 9$ & 3533 & $10 \cdot 4$ \\
\hline
\end{tabular}
have a very similar seroprevalence.

Table $1 H S V-1$ and $H S V$-2 seroprevalence by ethnic group, age, marital status and social class

HSV-1 seroprevalence rates show considerably less variation between ethnic groups, although black women born in the Caribbean or in Africa were more likely to be seropositive $(92 \%, 96 \%)$ than Asian women or women (black or white) born in the British Isles $(73 \%-80 \%)$.

A logistic regression analysis revealed different risk factors for HSV-1 and HSV-2 seropositivity. Table 2 gives $\chi^{2}$ significance tests for each factor when the others are accounted for. HSV-1 is strongly associated with ethnic group and with social class. There is a 


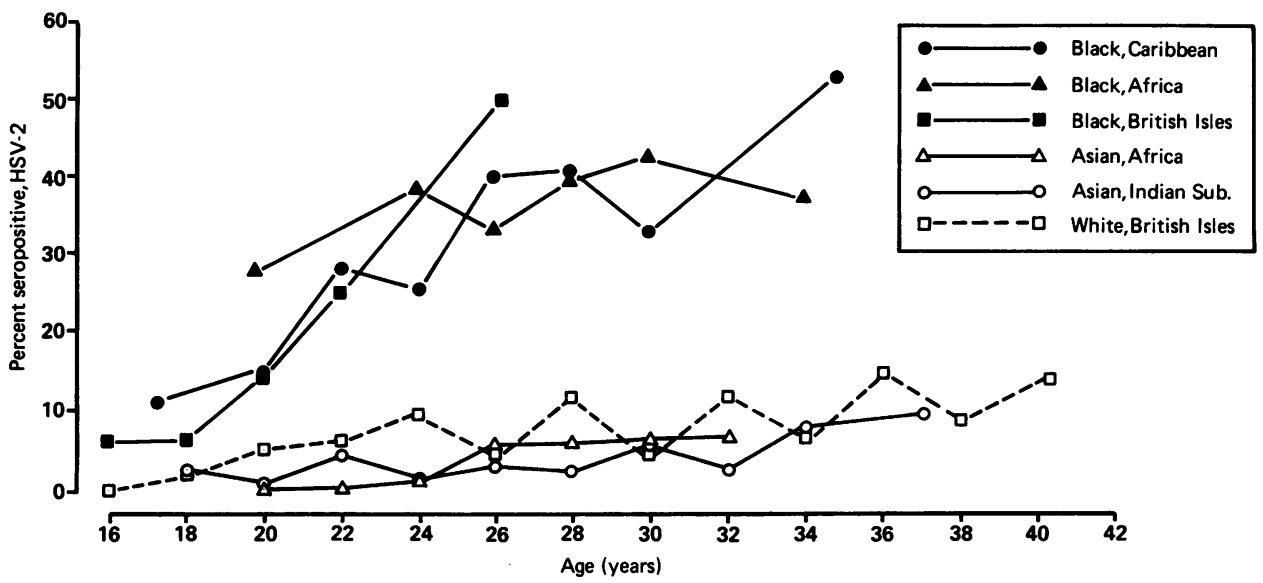

Figure Percent HSV-2 seropositive at each age, by ethnic group. (Age groups with less than 20 observations are excluded)

statistically significant relation with age, with the under 20 year group having lower seroprevalence and the over 35 year group having a higher seroprevalence, as might be expected from Table 1 .

Table 2 Logistic regression: likelihood ratio $\chi^{2}$ tests for statistical significance of each factor when all others are accounted for

\begin{tabular}{lccc}
\hline & & $\chi^{2}$ & \\
\cline { 3 - 4 } & $d f$ & $H S V-1$ & $H S V-2$ \\
\hline Ethic group & 5 & $88 \cdot 4 \dagger$ & $228 \cdot 9 \dagger^{\mathrm{a}}$ \\
Age & 4 & $18.9^{*}$ & $67 \cdot 2 \dagger$ \\
Marital status & 1 & $2 \cdot 4$ & $8 \cdot 0^{* a}$ \\
Social class & 2 & $40.0 \dagger$ & $4 \cdot 6$ \\
\hline
\end{tabular}

* $\mathrm{p}<0.005 ; \mathrm{p}<0.0001$.

$\mathrm{a}=$ Interaction between ethnic group and marital status: $\chi^{2}=17 \cdot 1, \mathrm{p}<0.005$.

Table 3 Percent seropositive HSV-1 (SEM) by social class, indirectly standardised within each ethnic group for age and marital status

\begin{tabular}{|c|c|c|c|}
\hline & Non-manual & Manual & Other \\
\hline $\begin{array}{l}\text { Asian } \\
\text { Indian subcontinent }\end{array}$ & $\begin{array}{l}52 \cdot 8 \\
(4 \cdot 6)\end{array}$ & $\begin{array}{l}76 \cdot 3 \\
(2 \cdot 8)\end{array}$ & $\begin{array}{l}76 \cdot 3 \\
(2 \cdot 2)\end{array}$ \\
\hline $\begin{array}{l}\text { Asian } \\
\text { Africa }\end{array}$ & $\begin{array}{l}64 \cdot 8 \\
(3 \cdot 6)\end{array}$ & $\begin{array}{l}73 \cdot 2 \\
(3 \cdot 7)\end{array}$ & $\begin{array}{l}68.5 \\
(3.8)\end{array}$ \\
\hline $\begin{array}{l}\text { White } \\
\text { British Isles }\end{array}$ & $\begin{array}{l}75 \cdot 3 \\
(2 \cdot 1)\end{array}$ & $\begin{array}{l}87 \cdot 2 \\
(2 \cdot 4)\end{array}$ & $\begin{array}{l}81 \cdot 5 \\
(1 \cdot 7)\end{array}$ \\
\hline $\begin{array}{l}\text { Black } \\
\text { British Isles }\end{array}$ & $\begin{array}{l}71 \cdot 6 \\
(5 \cdot 3)\end{array}$ & $\begin{array}{l}96 \cdot 6 \\
(11 \cdot 6)\end{array}$ & $\begin{array}{l}75 \cdot 1 \\
(3 \cdot 8)\end{array}$ \\
\hline $\begin{array}{l}\text { Black } \\
\text { Africa }\end{array}$ & $\begin{array}{l}93 \cdot 2 \\
(4 \cdot 7)\end{array}$ & $\begin{array}{l}99.5 \\
(4.5)\end{array}$ & $\begin{array}{l}97.0 \\
(3.0)\end{array}$ \\
\hline $\begin{array}{l}\text { Black } \\
\text { Caribbean }\end{array}$ & $\begin{array}{l}88 \cdot 0 \\
(3 \cdot 2)\end{array}$ & $\begin{array}{l}96 \cdot 9 \\
(5 \cdot 4)\end{array}$ & $\begin{array}{l}95.3 \\
(2.8)\end{array}$ \\
\hline
\end{tabular}

Table 4 Percent seropositive HSV-2 (SEM) by marital status, indirectly standardised within each ethnic group for age and social class

\begin{tabular}{|c|c|c|}
\hline & Single & $\begin{array}{l}\text { Married and/or } \\
\text { cohabiting }\end{array}$ \\
\hline $\begin{array}{l}\text { Asian } \\
\text { Indian subcontinent }\end{array}$ & - & $\begin{array}{c}3 \cdot 4 \\
(0 \cdot 7)\end{array}$ \\
\hline $\begin{array}{l}\text { Asian } \\
\text { Africa }\end{array}$ & - & $\begin{array}{c}3 \cdot 4 \\
(0 \cdot 9)\end{array}$ \\
\hline $\begin{array}{l}\text { White } \\
\text { British Isles }\end{array}$ & $\begin{array}{l}12 \cdot 2 \\
(2 \cdot 1)\end{array}$ & $\begin{array}{c}5 \cdot 8 \\
(0.8)\end{array}$ \\
\hline $\begin{array}{l}\text { Black } \\
\text { British Isles }\end{array}$ & $\begin{array}{l}13 \cdot 0 \\
(2 \cdot 3)\end{array}$ & $\begin{array}{l}21 \cdot 6 \\
(4 \cdot 3)\end{array}$ \\
\hline $\begin{array}{l}\text { Black } \\
\text { Africa }\end{array}$ & $\begin{array}{l}37.3 \\
(7.8)\end{array}$ & $\begin{array}{l}36 \cdot 3 \\
(4 \cdot 1)\end{array}$ \\
\hline $\begin{array}{l}\text { Black } \\
\text { Caribbean }\end{array}$ & $\begin{array}{l}36 \cdot 7 \\
(3 \cdot 7)\end{array}$ & $\begin{array}{l}29 \cdot 7 \\
(3 \cdot 2)\end{array}$ \\
\hline
\end{tabular}

HSV-1 seropositive rates for each social class category are presented in table 3 , standardised within ethnic groups for age and marital status. Women in the non-manual group had rates between $6.3 \%$ and $24 \%$ less than those in the manual group. Seroprevalence in the "other" category was generally between the manual and non-manual groups.

Seroprevalence for HSV -2 on the other hand was more strongly related to age and marital status, as well as ethnic group (table 2). When these factors were controlled for there was no association with social class. There was however a statistically significant interaction between ethnic group and marital status $\left(\chi^{2}\right.$ $=17.1, \mathrm{p}<0.005$ ), which is illustrated in table 4 . Among white women, the age and class standardised seroprevalence was twice as high in single women as 
in those married or cohabiting, whereas among the black groups the difference was less marked, and not present at all in those women born in the British Isles. (Under one percent of Asian women were single, so standardised rates have not been calculated for this group.) Other interactions between risk factors were tested but none were statistically significant at the $\mathrm{p}<0.05$ level.

\section{ESTIMATED SEROCONVERSION RATES}

The figure suggests that at any given age there is a similar HSV-2 seroprevalence among black women irrespective of country of birth. The three subgroups were therefore combined. Among white women, single and married have different age specific seroprevalence rates (table 4) and incidence rates were calculated separately because combining two groups with different age specific rates as well as different age distributions would lead to a seriously biased result.

Fitting models of the form of equation (3), with different values of $A_{o}$, no statistically significant improvement in fit was obtained beyond $k=0$ in any ethnic group, so it was assumed that seroconversion rates are constant across age. The best fitting values of $A_{0}$ ranged from 12.6 to 17.5 years.

The estimated seroconversion rates for each ethnic group are presented in table 5 . They vary from 2.5 and 4.1 per 1000 per year in Asian women to 6.0 in married white women, 11.9 in single white women, and 35.4 in black women. The estimated number of seroconversions occurring during 1000 pregnancies necessarily follows a similar pattern: 1.9-2.9 in Asian women, $4 \cdot 1-8.0$ in white women and about 20 in black women.

A different pattern emerges in the number of HSV-2 seroconversions estimated to occur in women who are seronegative for HSV-1. The high HSV-2 seroconversion rate in black women born in Africa or the Caribbean was offset by their high prevalence of HSV-1 antibody (95-96\%), so the estimated number of HSV-2 seroconversions in pregnancy that are primary HSV infections is comparable in Asian women, white women and black women born overseas (0.5-1.6 per 1000). Black women born in the British Isles, however, have a high HSV-2 seroconversion rate but only $76 \%$ are HSV -1 seropositive, and thus they run the highest risk of primary HSV infection in pregnancy (5.7 per 1000).

\section{Discussion}

\section{HSV-1 SEROPREVALENCE}

Seroprevalence of $\mathrm{HSV}-1$ antibody was relatively high: $80 \%$ in white women, $70 \%$ in Asian, $90 \%$ in black women born overseas and $75 \%$ in UK born black women. These results compare with $50-90 \%$
Table 5 Estimated $H S V-2$ annual seroconversion rates, and rates of $\mathrm{HSV}-2$ seroconversion in pregnancy, with standard errors in parentheses

\begin{tabular}{|c|c|c|c|c|}
\hline & \multirow[b]{2}{*}{$\begin{array}{l}\text { Sample } \\
\text { size }\end{array}$} & \multirow[b]{2}{*}{$\begin{array}{l}\text { Annual } H S V-2 \\
\text { seroconversion } \\
\text { rate per } 1000\end{array}$} & \multicolumn{2}{|c|}{$\begin{array}{l}\text { HSV-2 seroconversions per } \\
1000 \text { pregnancies }\end{array}$} \\
\hline & & & All women & $\begin{array}{l}H S V-1 \\
\text { negative } \\
\text { women }\end{array}$ \\
\hline $\begin{array}{l}\text { Asian, Indian } \\
\text { subcontinent }\end{array}$ & 742 & $\begin{array}{l}2.5 \\
(0.8)\end{array}$ & $\begin{array}{c}1.9 \\
(0.6)\end{array}$ & $\begin{array}{c}0.5 \\
(0.2)\end{array}$ \\
\hline Asian, Africa & 476 & $\begin{array}{c}4 \cdot 1 \\
(1 \cdot 2)\end{array}$ & $\begin{array}{r}2.9 \\
(0.8)\end{array}$ & $\begin{array}{l}0.9 \\
(0.3)\end{array}$ \\
\hline $\begin{array}{l}\text { White, British } \\
\text { Isles (single) }\end{array}$ & 338 & $\begin{array}{l}11 \cdot 9 \\
(2 \cdot 8)\end{array}$ & $\begin{array}{c}8 \cdot 0 \\
(1 \cdot 8)\end{array}$ & $\begin{array}{l}1.6 \\
(0.4)\end{array}$ \\
\hline $\begin{array}{r}\text { White, British } \\
\text { Isles (M/C) }\end{array}$ & 884 & $\begin{array}{c}6 \cdot 0 \\
(1 \cdot 1)\end{array}$ & $\begin{array}{c}4 \cdot 1 \\
(0 \cdot 7)\end{array}$ & $\begin{array}{l}0.8 \\
(0.2)\end{array}$ \\
\hline $\begin{array}{l}\text { Black, British } \\
\text { Isles }\end{array}$ & 251 & $\begin{array}{l}35 \cdot 4^{*} \\
(3 \cdot 3)\end{array}$ & $\begin{array}{l}22 \cdot 3 \\
(1 \cdot 8)\end{array}$ & $\begin{array}{c}5 \cdot 7 \\
(0.8)\end{array}$ \\
\hline Black, Africa & 167 & $\begin{array}{l}35 \cdot 4^{*} \\
(3 \cdot 3)\end{array}$ & $\begin{array}{l}17 \cdot 1 \\
(1 \cdot 1)\end{array}$ & $\begin{array}{l}0.7 \\
(0.3)\end{array}$ \\
\hline Black, Caribbean & 327 & $\begin{array}{l}35 \cdot 4^{*} \\
(3 \cdot 3)\end{array}$ & $\begin{array}{l}18 \cdot 0 \\
(1 \cdot 2)\end{array}$ & $\begin{array}{c}1.4 \\
(0.3)\end{array}$ \\
\hline
\end{tabular}

- Data pooled to give a single estimate

HSV-1 seroprevalence in a middle class population in Washington State, ${ }^{19} 50-70 \%$ in a largely black population in Atlanta, ${ }^{20}$ and $53 \%$ in white and $74 \%$ in black from a late 70 s nationwide American survey. ${ }^{21}$ Studies conducted in the 40 s and 50 s found $90 \%$ prevalence in almost all populations. ${ }^{22}$ A 1953 British survey of middle class children aged 3-15 found $85 \%$ had HSV-1 antibodies compared with $41 \%$ in $1965 .^{23}$ Our study gives little support to the suggestion ${ }^{1}$ that HSV-1 seroprevalence rates are falling in industrialised countries. Lower seroprevalence among women in higher social classes, which has been reported frequently, ${ }^{24}$ was confirmed in this study.

\section{HSV-2 SEROPREVALENCE}

The acquisition of HSV-2 is likely to be related to sexual activity: antibodies are rarely detected until puberty. According to one review $80 \%$ of female prostitutes had antibodies compared with only $3 \%$ of nuns. ${ }^{22}$ In a survey carried out in 1981 , about $15 \%$ of middle class white adults in Toronto aged between 22 and 45 years of age had HSV-2 antibodies and prevalence was strongly related to sexual activity. ${ }^{25}$ In women attending obstetric clinics in Seattle, HSV-2 antibodies were detected in $46 \%$ of lower socioeconomic class women and in $23 \%$ of middle class women. ${ }^{1}$ Recent sero-epidemiological studies in Atlanta, Georgia detected antibody to HSV-2 specific protein $G_{2}$ in $35 \%$ of women attending a health maintenance organisation gynaecology clinic. ${ }^{21}$ 
The results from North America tend to give higher HSV-2 seroprevalence than this study. This could partly be due to differences in laboratory methods. Although we have used a sensitive ELISA test, which is more likely to detect lower levels of antibodies than the neutralisation and complement fixation used in most earlier studies, ${ }^{22}{ }^{23}$ previous assay systems were less type specific, so that false HSV-2 positives may have been more frequent in groups with higher HSV-1 seroprevalence.

In this study HSV-2 seroprevalence depended strongly on ethnic group: $3 \cdot 4 \%$ of Asian women, $7 \cdot 2 \%$ of white and up to $38 \%$ of black women were seropositive. Control populations tested in studies of HSV-2 and cervical cancer have shown seroprevalence in black women twice that in whites. ${ }^{26}{ }^{27}$ In a national United States survey, HSV-2 antibodies were between 2 and 5 times more prevalent in black people than in whites. ${ }^{21}$ Social class was not an important risk factor in this population, in contrast to previous studies. ${ }^{25} 28$

ESTIMATED INCIDENCE OF HSV-2

The calculation of incidence from age specific prevalence rates ${ }^{14}$ assumes that antibodies persist, ${ }^{29}$ that there are no secular changes in incidence, and that there are no relevant differences between pregnant women of different ages. In view of changes in sexual behaviour in the last 30 years it is unlikely that the latter two assumptions could be defended. But so long as their limitations are understood, incidence estimates derived in this way may still throw light on the transmission of $\mathrm{HSV}-2$ and risk factors for neonatal HSV.

The relation between maternal and neonatal herpes is not properly understood. Factors that must be considered are the respective roles of $\mathrm{HSV}-1$ and HSV-2, of recurrent and primary maternal infection, and the protective effect of maternal antibody. About $80 \%$ of neonatal infection is caused by HSV-2 and $20 \%$ by HSV $-1 .{ }^{3}$ However, most of the latter infections appear to be acquired from non-maternal sources. ${ }^{30}$ Primary maternal infections are much more likely than recurrent infections to lead to neonatal infection. This may be due to the higher titre of virus shed, and the longer duration of shedding in primary infection, ${ }^{22}$ or to the protective effect of maternal antibodies in recurrent infection. In a recent study, 34 children were born to mothers with recurrent infection at delivery, but none acquired neonatal infection and their antibody levels were significantly higher than those of infected neonates. ${ }^{31}$ For these children exposed to recurrent maternal infection the upper $95 \%$ limit for the risk of transmission was $8 \%$. By contrast, primary infection at delivery is estimated to have a $50 \%$ risk of neonatal infection. ${ }^{32}$
Recurrent infections are more common than primary ones but the proportion of neonatal infections attributable to primary versus recurrent maternal genital infection is not known. In antenatal examinations it was found that $15 \%$ of women who were shedding HSV had primary infection and $85 \%$ recurrent. ${ }^{32}$ If we assume that the risks of transmission following primary and recurrent infection are $50 \%$ and $5 \%$ respectively, we should expect $65 \%$ of genitally acquired neonatal herpes to follow primary infection. This estimate agrees with data from Whitley et $a l^{33}$ who note that the majority of mothers of neonatally infected infants report no history of genital herpes.

Taken together the research described above suggests that the main risk factor for neonatal infection is primary HSV-2 infection. It is therefore of interest to consider how estimates of primary maternal HSV-2 incidence might relate to the reported occurrence of neonatal herpes. The average rate in white women was estimated to be about five primary infections per 1000 pregnancies. Assuming an 11 day period of viral shedding, ${ }^{34}$ and a $50 \%$ transmission rate, ${ }^{32} 10$ neonatal infections per 100000 births would be predicted. This is considerably higher than the 2-3 laboratory reports to the PHLS per 100000 births. One possible reason for the disagreement is that primary HSV-2 may be less likely to cause neonatal infection if the mother has HSV-1 antibodies. The two types are antigenically similar, ${ }^{1}$ and it is known that antibody response to HSV-2 is modified in adults with a previous HSV-1 infection. 34-36 In addition serological studies have shown that HSV-2 infected infants lack antibodies to both HSV-2 and HSV -1.23031

A primary HSV-2 infection in an HSV-1 seronegative woman was estimated to occur in about 1 per 1000 pregnancies, in all ethnic groups with the exception of black women born in the UK. On this basis two neonatal infections per 100000 would be expected. This is in much closer agreement with the numbers reported through the PHLS, which provides some support for the view that maternal HSV-1 antibody may protect against neonatal HSV-2. However, too much reliance cannot be placed on such a post hoc analysis. In particular our projection from maternal HSV-2 incidence to neonatal infection takes no account of changes in the sexual behaviour of either women or their partners as pregnancy progresses; and the PHLS figures will include non-maternally acquired infections, while excluding less severe and asymptomatic cases.

The American Academy of Paediatrics has recommended that women with a history of genital infection be cultured for HSV in the last weeks of pregnancy. ${ }^{37}$ Women with genital lesions or positive 
cultures were to be advised to have a caesarean delivery. However, our estimates of the incidence of neonatal herpes are based on primary maternal infection alone. To the extent that these estimates correspond fairly well to the observed rates, the present findings, in common with recent North American research, ${ }^{38}$ would tend to argue against a screening policy based on recurrent infection.

This research was funded by the Wellcome Trust. Dr M Forsgren of the Central Microbiological Laboratory, Stockholm, kindly provided the sera which enabled the specificity of the assay to be assessed.

Address for correspondence and reprints: $\operatorname{Dr} \mathrm{A}$ E Ades, Institute of Child Health, Paediatric Epidemiology Department, 30 Guilford Street, London WCIN 1EH.

\section{References}

${ }^{1}$ Corey L, Spear PG. Infections with herpes simplex viruses. $N$ Engl J Med 1986; 314: 686-91, 749-57.

2 Yeager AS, Arvin AM, Urbani LJ, Kemp JA. Relationship of antibody to outcome in neonatal herpes simplex virus infections. J Infect Immun 1980; 29: 532-8.

${ }^{3}$ Nahmias AJ, Keyserling HH, Kerick G. Herpes simplex. In: Remington JS, Klein JO, eds. Infectious diseases of the fetus and newborn infant. Philadelphia: WB Saunders, 1983: 636-78.

${ }^{4}$ Nahmias AJ, Alford CA, Korones SB. Infections of the newborn with herpesvirus hominis. Adv Pediatr 1971; 17: 185-226.

${ }^{5}$ PHLS report. Report from the PHLS Communicable Disease Surveillance Centre. Br Med J 1987; 294: 361-2.

${ }^{6}$ Hindley D, Adler M. Genital herpes: an increasing problem? Genitourin Med 1985; 61: 56-8.

${ }^{7}$ PHLS report. Sexually transmitted disease surveillance in Britain-1984. Br Med J 1986; 293: 942-3.

${ }^{8}$ Graham S, Rawls W, Swanson M, McCurtis J. Sex partners and herpes simplex virus type 2 in the epidemiology of cancer of the cervix. Am J Epidemiol 1982; 115: 729-35.

${ }^{9}$ Svennerholm B, Olofsson S, Jeansson S, Vahlne A, Lycke E. Herpes simplex virus type-selective enzyme-linked immunosorbent assay with Helix Pomatia lectin-purified antigens. J Clin Microbiol 1984; 19 235-9.

${ }^{10}$ Peckham C, Coleman J, Hurley R, Chin K, Henderson K. Cytomegalovirus infection in pregnancy: preliminary findings from a prospective study. Lancet 1983; i: 1352-6.

11 Jeansson S, Forsgren M, Svennerholm B. Evaluation of solubilized herpes simplex virus membrane antigen by enzyme-linked immunosorbent assay. J Clin Microbiol 1983; 18: $1160-6$.

12 Baker R, Nelder J. The GLIM system release 3. Oxford Numerical Algorithms Group, 1978.

13 Anderson RM, May RM. Vaccination against rubella and measles: quantitative investigations of different policies. $J$ Hyg (Cambridge) 1983; 90: 259-325.

14 Papoz L, Simondon F, Saurin W, Sarmini H. A simple model relevant to toxoplasmosis applied to epidemiologic results in France. Am J Epidemiol 1986; 123: $154-61$.
${ }^{15}$ Grenfell BT, Anderson RM. The estimation of age-related rates of infection from case notifications and serological data. J Hyg (Cambridge) 1985; 95: 419-36.

${ }^{16}$ Cox DR, Oakes D. Analysis of survival data. London: Chapman and Hall, 1984.

${ }^{17}$ Griffiths DA. A catalytic model of infection for measles. Appl Statistics 1974; 23: 330-9.

${ }^{18}$ Wacholder S. Binomial regression in GLIM: estimating risk ratios and risk differences. Am J Epidemiol 1986; 123: 174-84.

${ }^{19}$ Wentworth BB. Seroepidemiology of infections due to members of the herpesvirus group. Am J Epidemiol 1971; 94: 496-507.

${ }^{20}$ Nahmias A, Josey W, Naib Z, Luce C, Duffey A. Antibodies to herpesvirus hominis types 1 and 2 in humans. I. Patients with genital herpetic infections. Am J Epidemiol 1970; 91: 539-46.

${ }^{21}$ Nahmias A, Keyserling H, Lee F. Epidemiology of herpes simplex viruses. In: Evans A, ed. Viral infections of humans. New York: Plenum Press (In press).

22 Nahmias A, Roizman B. Infection with herpes-simplex virus 1 and 2. $N$ Engl J Med 1973; 289: 667-74, 719-25, 781-9.

${ }^{23}$ Smith I, Peutherer J, MacCallum F. The incidence of herpes virus hominus antibody in the population. $J \mathbf{H y g}$ (Cambridge) 1967; 65: 395-408.

${ }^{24}$ Rawls WE, Campione-Piccardo J. The epidemiology of herpes simplex virus type 1 and type 2 infections. In: Nahmias AJ, Dowdle WR, Schinazi RF, eds. The human herpes viruses. New York: Elsevier, 1981: 137-52.

${ }^{25}$ Stavraky K, Rawls W, Chiavetta J, Donner A, Wanklin J. Sexual and socioeconomic factors affecting the risk of past infections with herpes simplex virus type 2 . Am J Epidemiol 1983; 118: 109-21.

${ }^{26}$ Rawls W, Adam E, Melnick J. Geographical variation in the association of antibodies to herpes virus type 2 and carcinoma of the cervix. In: De The G, Biggs PM, eds. Oncogeneses and herpesviruses. Lyon: IARC Scientific Publication 2, 1972: 424-7.

${ }^{27}$ Adam E, Kaufman RH, Melnick JL, Levy AH, Rawls WE. Seroepidemiologic studies of herpes virus type 1 and 2 and carcinoma of the cervix. III Houston, Texas. Am J Epidemiol 1972; 96: 427-42.

${ }^{28}$ McDonald AD, Williams MC, West R, Stewart J. Neutralizing antibodies to herpes virus types 1 and 2 in Montreal women. Am J Epidemiol 1974; 100: 124-9.

${ }^{29}$ Morris G, Coleman R, Best J, Benetato B, Nahmias A. Persistence of serum IgA antibodies to herpes simplex, Varicella-Zoster, cytomegalovirus and rubella virus detected by enzyme-linked immunosorbent assays. J Med Virol 1985; 16: 343-9.

${ }^{30}$ Yeager AS, Arvin AM. Reasons for the absence of a history of recurrent genital infections in mothers of neonates infected with herpes simplex virus. Pediatrics 1984; 73: 188-93.

${ }^{31}$ Prober CG, Sullender WM, Yasukawa LL, Au DS, Yeager AS, Arvin AM. Low risk of herpes simplex virus infections in neonates exposed to the virus at the time of vaginal delivery to mothers with recurrent genital herpes simplex virus infection. $N$ Engl J Med 1987; 316: $240-4$.

32 Nahmias AJ, Josey WE, Naib ZM, Freeman MG, Fernandez RJ, Wheeler JH. Perinatal risks associated with maternal genital herpes simplex virus infection. $\mathbf{A m ~ J}$ Obstet Gynecol 1971; 110: 825-33.

${ }^{33}$ Whitley RJ, Nahmias AJ, Visintine AM, Fleming CL, Alford CA. The natural history of herpes simplex virus infection of mother and newborn. Pediatrics 1980; 66: 489-94. 
${ }^{34}$ Corey L, Adams H, Brown Z, Holmes K. Genital herpes simplex infections: clinical manifestations, course and complications. Ann Int Med 1983; 98: 958-72.

${ }^{35}$ Smith JW, Adam E, Melnick JL, Rawls JE. Use of ${ }^{51} \mathrm{Cr}$ release test to demonstrate patterns of antibody response in humans to herpes virus types 1 and $2 . J$ Immunol 1972; 109: 554-64.

${ }^{36}$ McClung H, Seth P, Rawls W. Relative concentrations in human sera of antibodies to cross-reacting and specific antigens of herpes simple virus types 1 and 2 . Am J Epidemiol 1976; 104: 192-201.
${ }^{37}$ Committee on Fetus and Newborn. Perinatal herpes simplex virus infection. Pediatrics 1980; 66: 147-8.

${ }^{38}$ Prober CG, Hensleigh P, Boucher F, Yasukawa LL, Au DS, Arvin AM. Use of routine viral cultures at delivery to identify neonates exposed to herpes simplex virus. New Engl J Med 1988; 318: 887-91.

Accepted for publication October 1988 